\title{
The Mode of Action of Carp Gonadotropin on the Stimulation of Androgen Production by Carp Testis in Vitro
}

\author{
Yea-Sha Chang and Fore-Lien Huang ${ }^{1}$ \\ 'Institute of Biological Chemistry, Academia Sinica, P.O. Box 23-106, Taipei, Taiwan
}

Accepted September 25, 1981

\begin{abstract}
Carp gonadotropin (cGTH) can stimulate carp testis to produce androgen in vitro. This action can be mimicked by dibutyryl cAMP $\left(\mathrm{Bt}_{2} \mathrm{cAMP}\right)$ and prostaglandins (PG). $\mathrm{Bt}_{2} \mathrm{cAMP}$ can enhance the androgen production when submaximal doses of cGTH are used but cannot do so when maximal dose of cGTH is used. PG $F_{2 \alpha}$ is more effective than PG $E_{1}$ and $E_{2}$. Buth the inhibitors of RNA and protein synthesis can interfere the stimulatory effect of cGTH. Actinomycin D has $87 \%$ while cycloheximide has $100 \%$ inhibition. The stimulatory effect of cGTH is much more dependent on de novo protein synthesis than on RNA synthesis. In addition, steroidogenesis inhibitors, glutethemide, metyrapone, and spirocyanoketone, can also inhibit the stimulatory effect of cGTH on androgen production.
\end{abstract}

Luteinizing hormone ( $\mathrm{LH})$ can stimulate testis to produce androgen in higher vertebrates either in vivo or in vitro (Cigorraga et al., 1978; Cooke et al., 1975, 1979; Dufau et al., 1971; Hafiez et al., 1972; Maung and Follett, 1977; Mendelson et al., 1975; Muller, 1977). The available evidences indicate that cyclic adenosine $3^{\prime}, 5^{\prime}$-monophosphate (cAMP) is an intracellular messenger of $\mathrm{LH}$ on androgen production (Cigorraga et al., 1978; Cooke et al., 1979; Dufau et al., 1971; Rommertz et al., 1974). The stimulatory effect of $\mathrm{LH}$ on androgen production is dependent on de novo protein synthesis since ribonucleic acid (RNA) and protein synthesis inhibitors can inhibit the stimulatory effect of LH (Cigorraga et al., 1978; Cooke $e t$ al., 1975, 1979; Dufau et al., 1974; Mendelson et al., 1975; Moyle et al., 1971; Shin and Sato, 1971). The effect of LH on androgen production is mainly due to its promotion of the conversion of cholesterol to pregnenolone (Bakker et al., 1978; Cigorraga et al., 1978; Hall and Eik-Nes, 1964; Hall and Young, 1968; Purvis et al., 1973; van der Vusse et al., 1975).

Our previous results indicated that fish

\footnotetext{
1 To whom all correspondence should be sent.
}

gonadotropin (GTH) can stimulate male carp to produce androgen either in vivo (Jean, 1980) or in vitro (Huang and Chang, 1980). The mode of action of fish GTH has seldom been investigated. Only a few lines of evidence indicate that fish GTH can enhance the fish gonad to produce cAMP (Fontaine et al., 1970; Fontaine-Bertrand $e t$ al., 1978; Idler et al., 1975). In this study attempts are made to investigate the mode of action of carp GTH (cGTH) on the stimulation of androgen production by carp testis in vitro by the following approaches: (1) whether dibutyryl cAMP ( $\left.\mathrm{Bt}_{2} \mathrm{cAMP}\right)$ and prostaglandins (PG) can mimic the action of cGTH, (2) whether the stimulatory effect of cGTH is dependent on de novo RNA and protein synthesis, and (3) whether the various kinds of steroidogenesis inhibitors effective in mammalian systems can inhibit the stimulatory effect of cGTH on androgen production.

\section{MATERIALS AND METHODS}

Chemicals. Actinomycin D, bovine serum albumin (BSA), chick ovomucoid, cycloheximide, $\mathrm{Bt}_{2}$ cAMP, $P G E_{1}, E_{2}$ and $F_{2 \alpha}$, and steroids were purchased from Sigma, St. Louis, Missouri. [ $\left.{ }^{3} \mathrm{H}\right]$ Testosterone was from the Radiochemical Center, Amersham, England. Ether was from Wako Pure Chemical Industries, 
Japan. Glutethemide (3-phenyl-3-ethyl-2,6-dioxopiperidin) and metyrapone (2-methyl-1,2-di-3-pyridyl1-propanone) were the kind gifts from Dr. J. Y. Chang, Ciba Company, Basel. Spirocyanoketone ( $2 \alpha$-cyano4,4-dimethyl-20-spirox-5-en-3-one) was the kind gift from Dr. G. H. Rasmusson, Merck, Sharp and Dohme Research Laboratories, New Jersey. The cGTH used in this study was prepared as previously described (Huang and Chang, 1980). For assay, actinomycin D, cycloheximide, $\mathrm{Bt}_{2} \mathrm{cAMP}$, and glutethemide were dissolved in incubation medium (see below) whereas metyrapone, PGs, and spirocyanoketone were dissolved in absolute alcohol.

Androgen production by carp testis in vitro. The method for the assay of the effect of cGTH and other substances on androgen production by carp testis in vitro was the same as previously described (Huang and Chang, 1980). Mature male carps (Cyprinus carpio L.) were collected during breeding season (December to March). Their body weights and gonadosomatic indexes (testis wt/body wt $\times 100$ ) were from 300 to $500 \mathrm{~g}$ and 15 to 25 , respectively. Testes from 3 to 4 fishes were pooled and finely chopped. The chopped tissues were washed with washing medium (8/9 strength of Krebs-Ringer bicarbonate buffer, $\mathrm{pH} 7.4$, supplemented with $0.1 \% \mathrm{BSA}$ and $0.03 \%$ chick ovomucoid) until no whitish material was left in the supernatant. The washed tissues were preincubated in washing medium under $95 \% \mathrm{O}_{2}-5 \% \mathrm{CO}_{2}$ for $15 \mathrm{~min}$ and then centrifuged at $5000 \mathrm{~g}$ for $10 \mathrm{~min}$ to remove excess medium. For assay, $200 \mathrm{mg}$ of preincubated tissue were suspended in $2 \mathrm{ml}$ of incubation medium (same as washing medium except $1 \mathrm{~m} M$ theophylline was supplemented). An aliquot containing a given quantity of cGTH or other substances was also added to the incubation medium. For those alcohol-soluble substances, a given quantity in $10 \mu \mathrm{l}$ of absolute alcohol was added. Vehicle alone was served as control. In this study, samples for all assays in a set of experiment (i.e., all assays included in a given figure) were derived from a same batch of tissue preparation unless otherwise indicated. Triplicate determinations were made for each assay.

Incubation was performed at $25^{\circ}$ under $95 \% \mathrm{O}_{2}-5 \%$ $\mathrm{CO}_{2}$ with slow constant shaking for $4 \mathrm{hr}$ and terminated by centrifugation $(5000 \mathrm{~g}$ for $10 \mathrm{~min}$ ). The supernatant was extracted with ether and then the androgen content was measured by radioimmunoassay as previously described. The antiserum used was raised against testosterone 17-hemisuccinate BSA conjugate. By using testosterone as reference $(100 \%)$, the antiserum had $153 \%$ and $6 \%$ cross-reactivity toward androstenedione and 11 -ketotestosterone, respectively.

Evaluation of the effect of $B t_{2} c A M P, P G s$, and inhibitors on androgen production. The dose-response curve of the stimulatory effect of cGTH on carp testis to produce androgen is nonlinear (see Results). For evaluation of the stimulatory effect of $\mathrm{Bt}_{2} \mathrm{cAMP}$ and PGs, the amount of androgen produced was intrapolated into the dose-response curve of cGTH to get the equivalent amount of cGTH by which similar amount of androgen was produced. For evaluation of the inhibitory effect of inhibitor on the action of cGTH, carp testis was incubated with $0.8 \mu \mathrm{g} \mathrm{cGTH}$ in the absence or presence of inhibitor. Similar intrapolation as that mentioned above was also made to get the equivalent amount of cGTH (in the unit of $\mu \mathrm{g}$ ) in the presence of inhibitor and denoted as eq-cGTH ${ }_{i n h}$. The percentage of inhibition was calculated as $\left(1-\right.$ eq-cGTH $\left.{ }_{i n h} / 0.8\right) \times$ $100 \%$.

\section{RESULTS}

\section{The Stimulatory Effect of cGTH}

The cGTH can stimulate carp testis to produce androgen in vitro. The range of dose-response curve is from 0.1 to $1.6 \mu \mathrm{g}$, and in certain cases to $3.2 \mu \mathrm{g}$ (Figs. 1 and 3). The time course of androgen production under the stimulation of cGTH is shown in Fig. 4. The rate of androgen production is slower at the earlier than at the later period of incubation.

\section{The Effect of $\mathrm{Bt}_{2}$ cAMP}

The $\mathrm{Bt}_{2}$ cAMP can stimulate carp testis to produce androgen in vitro. The effect of $1,5,10$, and $20 \mathrm{mM} \mathrm{Bt}_{2} \mathrm{cAMP}$ are equivalent to $0.10,0.20,0.64$, and $0.90 \mu \mathrm{g}$ of

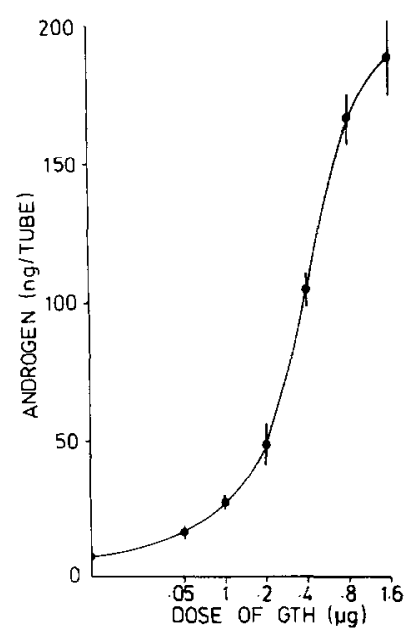

FIG. 1. The dose-response curve of cGTH on the stimulation of androgen production by carp testis in vitro. Each point and line indicate the mean \pm SD of triplicate determinations. 
cGTH on the aspect of the stimulation of androgen production (Fig. 2).

When $\mathrm{Bt}_{2}$ cAMP and $\mathrm{cGTH}$ are added together to the incubation medium, the effect is always higher than that when either of them is present alone in the incubation medium. These results indicate that $\mathrm{Bt}_{2}$ cAMP can express its effect in the presence of cGTH. However, the extent of the effect of $\mathrm{Bt}_{2} \mathrm{CAMP}$ is dependent on the concentration of coexisting cGTH. At the lower concentration of cGTH $(0.1-0.4 \mu \mathrm{g})$, the effect of $\mathrm{Bt}_{2} \mathrm{cAMP}$ and $\mathrm{cGTH}$ are additive. When the concentration of cGTH is increased up to $0.8 \mu \mathrm{g}$ and more, the effect of $\mathrm{Bt}_{2}$ cAMP becomes progressively less and finally disappears (Fig. 3). Under the stimulation of maximal dose of cGTH, the amount of androgen produced is the same whether $\mathrm{Bt}_{2}$ cAMP is present or not. Thus the effect of $\mathrm{Bt}_{2} \mathrm{cAMP}$ is completely masked by maximal dose of cGTH.

\section{The Effect of $P G$}

As shown in Fig. 2, PG $E_{1}, E_{2}$, and $F_{2 \alpha}$ have stimulatory effect on androgen production. At the concentration of $20 \mu \mathrm{g} / \mathrm{ml}$,

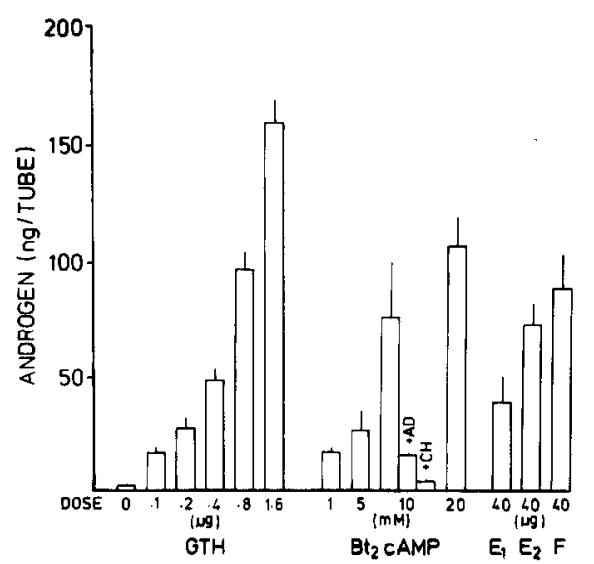

Fig. 2. The stimulatory effects of $\mathrm{Bt}_{2} \mathrm{cAMP}, \mathrm{PG} \mathrm{E}_{1}$, $\mathrm{E}_{2}$, and $\mathrm{F}_{2 \alpha}$ on androgen production by carp testis in vitro, and the inhibitory effects of actinomycin $\mathrm{D}$ (AD) and cycloheximide $(\mathrm{CH})$ on $\mathrm{Bt}_{2}$ cAMP. The doses of $\mathrm{cGTH}, \mathrm{Bt}_{2} \mathrm{cAMP}$, and PGs are shown in the figure whereas those of actinomycin $D$ and cycloheximide are $0.1 \mathrm{mM}$. Each bar and line indicate the mean and standard deviation of triplicate determinations.

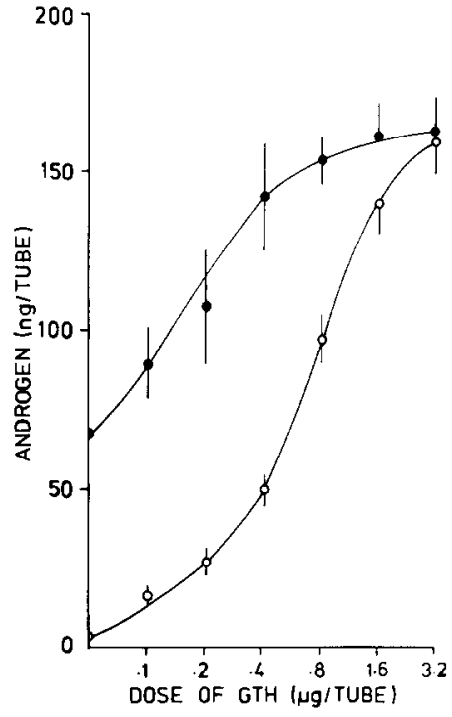

FIG. 3. The effects of $\mathrm{Bt}_{2} \mathrm{cAMP}$ and cGTH on the stimulation of androgen production by carp testis in vitro. The doses of cGTH used are shown in the figure whereas that of $\mathrm{Bt}_{2} \mathrm{cAMP}$ is $10 \mathrm{mM}$. $\mathrm{O}, \mathrm{cGTH}$ is present alone; - , cGTH and $\mathrm{Bt}_{2}$ cAMP are coexisting. Each point and line indicate the mean \pm SD of triplicate determinations.

the effect of PG $E_{1}, E_{2}$, and $F_{2 \alpha}$ are equivalent to $0.33,0.62$, and $0.73 \mu \mathrm{g}$ of $\mathrm{cGTH}$, respectively.

\section{The Effect of Actinomycin $D$ and Cycloheximide}

When the concentration of actinomycin $\mathrm{D}$ is kept at $0.01 \mathrm{~m} M$, the stimulatory effect of cGTH on androgen production is inhibited by $87 \%$ (Fig. 6). The inhibitory effect of actinomycin D becomes progressively less marked as the interval between the addition of cGTH and actinomycin D is increased. When the time interval is increased up to 3 $\mathrm{hr}$, actinomycin D has no more effect (Fig. 4). In addition, actinomycin $\mathrm{D}$ can also inhibit the stimulatory effect of $\mathrm{Bt}_{2} \mathrm{cAMP}$ on androgen production (Fig. 2).

When added simultaneously with cGTH, $0.1 \mathrm{~m} M$ of cycloheximide can completely abolish the stimulatory effect of cGTH. Furthermore, the amount of androgen produced by the tissue in the coexistence of cycloheximide and $\mathrm{cGTH}$ is even lower 


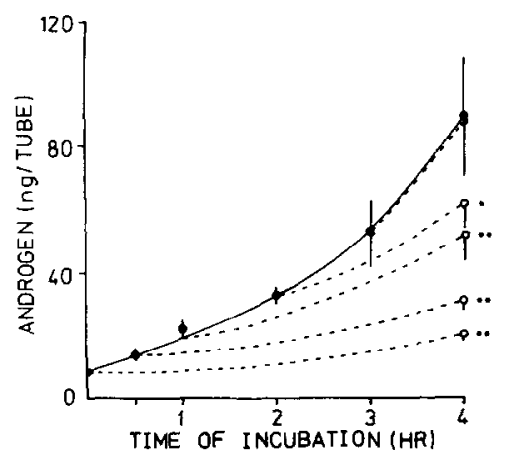

FIG. 4. The effect of actinomycin $D$ added at various time intervals of incubation on the androgen production by carp testis in vitro under the stimulation of cGTH. The doses used for cGTH and actinomycin D are $0.8 \mu \mathrm{g}$ and $0.01 \mathrm{~m} M$, respectively. and lines, means \pm SD of triplicate determinations of control; $O$ and lines, means and SD of triplicate determinations in which actinomycin $D$ is added at various time intervals and incubation is allowed to continue up to $4 \mathrm{hr}$. ${ }^{* *} P<$ 0.05 and $* P<0.10$ versus control of $4-$ hr incubation, respectively.

than that produced by the control tissue (significant at $10 \%$ but not at $5 \%$ level) (Fig. 6). In contrast with actinomycin $D$, the inhibitory effect of cycloheximide on the cGTH does not become lessened as the time interval between the addition of cGTH and cycloheximide is increased. Whenever the cycloheximide is added, the effect of cGTH is abolished (Fig. 5). The statistical analysis indicates that the amount of androgen produced by control group within a given time interval is not different significantly from that produced by the group in which cycloheximide is added at a given time interval and incubation is allowed to continue for another time interval up to 4 hr. In addition, cycloheximide can also abolish the stimulatory effect of $\mathrm{Bt}_{2}$ cAMP on androgen production (Fig. 2).

\section{The Effect of Steroidogenesis Inhibitors}

As shown in Fig. 6, the three types of inhibitors effective in mammalian systems are also effective in carp testis. At the concentration of 2,2 , and $0.02 \mathrm{mM}$, glutethemide, metyrapone, and spirocyanoketone have $95.8,84.0$, and $73.0 \%$ of inhibition on the stimulatory effect of cGTH on androgen production, respectively.

\section{DISCUSSION}

The stimulation of testis to produce androgen is one of the main effects of $\mathrm{LH}$ in higher vertebrates (Cigorraga et al., 1978; Cooke et al., 1979; Dufau et al., 1971; Hafiez et al., 1972; Maung and Follett, 1977; Mendelson et al., 1975; Muller, 1977). The testis or its dispersed Leydig cells has been used by many investigators as a model system to probe the mode of action of $\mathrm{LH}$ on steroidogenesis (Bakker et al., 1978; Cigorraga et al., 1978; Cooke et al., 1975, 1979; Hall and Eik-Nes, 1964; Hall and Young, 1968; Mendelson et al., 1975; Purvis et al., 1973; van der Vusse et al., 1975). Recently, we have demonstrated that fish GTH can stimulate carp testis to produce androgen in vitro (Huang and Chang, 1980), therefore attempts have been made to use this newly developed system as a model to investigate the mode of action of fish GTH.

The action of LH on steroidogenesis is proposed to be via the cAMP as cellular

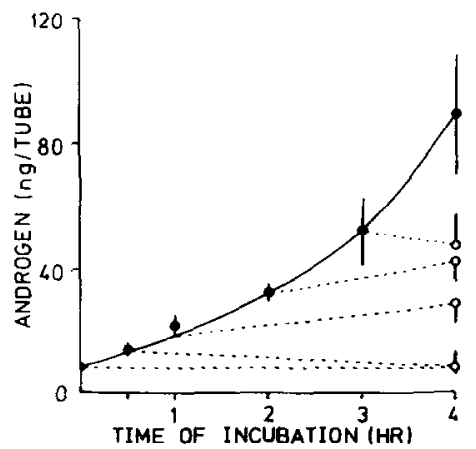

FIG. 5. The effect of cycloheximide added at various time intervals of incubation on the androgen production by carp testis in vitro under the stimulation of cGTH. The doses used for cGTH and cycloheximide are $0.8 \mu \mathrm{g}$ and $0.1 \mathrm{mM}$, respectively. and lines, means \pm SD deviations of triplicate determinations of control; $O$ and lines, means and SD of triplicate determinations in which cycloheximide is added at various time intervals and incubation is allowed to continue up to $4 \mathrm{hr}$. The same batch of tissue is used for assays of Figs. 4 and 5. 


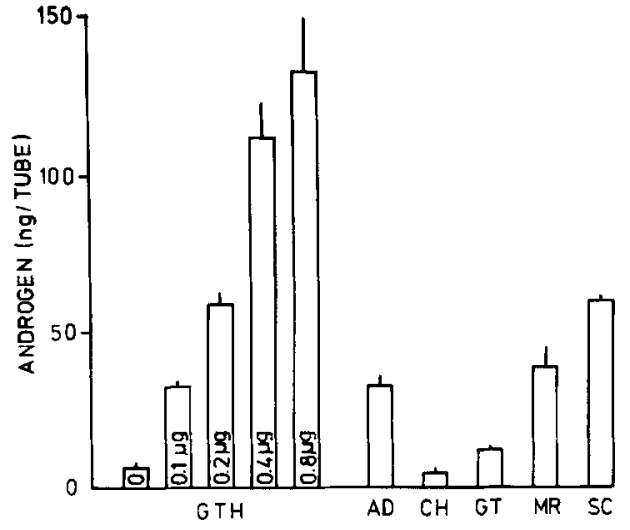

FIG. 6. The effects of inhibitors of RNA and protein synthesis, and steroidogenesis on androgen production by carp testis in vitro under the stimulation of cGTH. The doses of cGTH used for dose-response curve are shown inside the bar whereas those for assay of the inhibitory effect of various inhibitors are $0.8 \mu \mathrm{g}$. The doses of inhibitors used are as follows: actinomycin $\mathrm{D}$ (AD), $0.01 \mathrm{mM}$; cycloheximide (CH), $0.1 \mathrm{mM}$; glutethemide (GT), $2 \mathrm{mM}$; metyrapone (MR), $2 \mathrm{mM}$; spirocyanoketone (SC), $0.02 \mathrm{mM}$. Each bar and line indicate the mean and SD of triplicate determinations.

messenger (Cigorraga et al., 1978; Cooke et al., 1979; Dufau et al., 1971; Rommertz et al., 1974). It is also demonstrated that $\mathrm{Bt}_{2}$ cAMP can stimulate androgen production by carp testis in the present study. This finding seems to suggest that the action of cGTH may also be through cAMP as the second messenger.

The effects of $P G E_{1}, E_{2}$, and $F_{2 \alpha}$ on steroidogenesis are variable depending on the type of steroid, type of tissue and species of animal investigated (Behrman and Hichens, 1976; Erickson and Ryan, 1975, 1976; Labhsetwar, 1974; Lindner et al., 1974; McNatty et al., 1975; Neal et al., 1975; Patwardhan and Lanthier, 1977). The present results provide additional evidence that PG $F_{1}, E_{2}$, and $F_{2 \alpha}$ can also stimulate carp testis to produce androgen. Whether the stimulation of PGs on androgen production in carp testis is through the stimulation of cAMP formation as found in mouse ovary (Kuehl et al., 1970) remains to be elucidated.

The present results indicate that the stimulatory effect of cGTH on androgen production by carp testis is dependent on de novo RNA and protein synthesis because actinomycin $\mathrm{D}$ and cycloheximide can inhibit or abolish this effect. A similar situation is also found in the mammalian system (Cigorraga et al., 1978; Cooke et al., 1979; Dufau et al., 1974; Mendelson et al., 1975; Moyle et al., 1971; Shin and Sato, 1971). In rat the dependence of stimulatory effect of $\mathrm{LH}$ on de novo protein synthesis is more than that on de novo RNA synthesis. The inhibitory effect of actinomycin $\mathrm{D}$ becomes progressively less marked as the time interval between the addition of $\mathrm{LH}$ and actinomycin D is extended and finally disappears if the interval is increased up to $2.5 \mathrm{hr}$. On the other hand, even when cycloheximide is added $2.5 \mathrm{hr}$ following $\mathrm{LH}$, it can still affect the testosterone production although the extent is lessened relatively (Mendelson et al., 1975). In carp, the dependence of stimulatory effect of cGTH on de novo RNA synthesis becomes progressively less marked and finally becomes independent if the time interval between the addition of cGTH and actinomycin D is long enough. On the contrary, the stimulatory effect of cGTH is stringently dependent on the de novo protein synthesis. Cycloheximide can abolish the effect of cGTH whenever it is added to the incubation medium. Our data suggest that $\mathrm{cGTH}$ can induce the synthesis of regulatory proteins including enzymes for steroidogenesis by which androgen production in carp testis is stimulated. These regulatory proteins are very labile, therefore the stimulatory effect of cGTH is dependent on their continuous synthesis. The finding that the inhibitory effect of actinomycin $D$ becomes less marked or even totally insignificant may suggest that the messenger RNAs for these regulatory proteins are comparatively more stable and can be accumulated. Other possibilities are not excluded, such as the presence of lag period for actinomycin $\mathrm{D}$ to penetrate into the testicular tissue. 
The present results indicate that glutethemide, an inhibitor of cholesterol $20 \alpha$-hydroxylase (Kahnt and Neher, 1966), metyrapone, an inhibitor of cytochrome $\boldsymbol{P}$ 450-linked reactions (Satre and Vignais, 1974) and spirocyanoketone, an inhibitor of $\mathrm{C}_{19^{-}}$and $\mathrm{C}_{21^{-}}-3 \beta$-hydroxysteroid dehydrogenase (Goldman and Sheth, 1973) can inhibit the stimulatory effect of cGTH on androgen production by carp testis. The fact that the stimulatory effect of cGTH can be almost completely abolished by glutethemide indicates that the conversion of cholesterol to pregnenolone is necessary for expression of cGTH effect on androgen synthesis. The regulatory role of $\mathrm{LH}$ on the conversion of cholesterol to pregnenolone has been well demonstrated in mammals (Bakker et al., 1978; Cigorraga et al., 1978; Hall and EikNes, 1964; Hall and Young, 1968; Purvis et al., 1973; van der Vusse et al., 1975). Whether the conversion of cholesterol to pregnenolone in carp testis is also under the control of cGTH is currently being investigated in this laboratory.

\section{ACKNOWLEDGMENTS}

The authors express their sincere appreciation to Professor T. B. Lo, Dean of Science College, National Taiwan University, for his encouragement and advice. This work was financially supported by the National Science Council of the Republic of China (NSC-700203-B001-03)

\section{REFERENCES}

Bakker, C. P., van der Plan-van Winsen, M. P. I., and van der Molen, J. J. (1978). Effect of cytosol fractions from lutropin-stimulated rat testes on pregnenolone production by mitochondria from normal rat testes. Biochim. Biophys. Acta 543, 235-242.

Behrman, H. R., and Hichens, M. (1976). Regulation of ovarian steroid secretion. Prostaglandins 12, 83-95.

Cigorraga, S. K., Dufau, M. L., and Catt, K. J. (1978). Regulation of luteinizing hormone receptors and steroidogenesis in gonadotropin-desensitized Leydig cells. J. Biol. Chem. 253, 4297-4304.

Cooke, B. A., Janszen, F. H. A., Clotscher, W. F., and van der Molen, H. J. (1975). Effect of protein-synthesis inhibitors on testosterone production in rat testis interstitial tissue and Leydigcell preparation. Biochem. J. 150, 413-418.

Cooke, B. A., Lindh, L. M., Janızen, F. H. A., van
Driel, M. J. A., Bakker, C. P., van der Plank, M. P. I., and van der Molen, H. J. (1979). A Leydig cell tumor: A model for the study of lutropin action. Biochim. Biophys. Acta 583, 320-331.

Dufau, M. L., Catt, K. J., and Tsuruhara, T. (1971). Gonadotropin stimulation of testosterone production by the rat testis in vitro. Biochim. Biophys. Acta 252, 574-579.

Dufau, M. L., Mendelson, C., and Catt, K. J. (1974). A highly sensitive in vitro bioassay for luteinizing hormone and chorionic gonadotropin: Testosterone production by dispersed Leydig cells. J. Clin. Endocrinol. Meta. 39, 610-613.

Erickson, G. F., and Ryan, K. J. (1975). Effect of LH/FSH, dibutyryl cyclic AMP and prostaglandins on the productions of estrogens by rabbit granulosa cells in vitro. Endocrinology 97, 108-113.

Erickson, G. F., and Ryan, K. J. (1976). Stimulation of testosterone production in isolated rabbit thecal tissue by $\mathrm{LH} / \mathrm{FSH}$, dibutyryl cyclic AMP, PG $\mathrm{F}_{2 \alpha}$ and $\mathrm{PG} \mathrm{E}_{2}$. Endocrinology 99, 452-458.

Fontaine, Y. A., Burzawa-Gerard, E., and Delerue-Le Belle, N. (1970). Stimulation hormonale de l'activité adényl cyclasique de l'ovaire d'un poisson téléostéen, le cyprin (Carassius auratus L.). C.R. Acad. Sci. Paris Ser. D 271, 780-783.

Fontaine-Bertrand, E., Salmon, C., and Fontaine, Y. A. (1978). Effect d'hormones gonadotropes, in vitro, sur la concentration de l'adenosine monophosphate cyclique dans l'ovaire de l'anguille (Anguilla anguilla L.). Ann. Biol. Anim. Biochim. Biophys. 18, 805-811.

Goldman, A. S., and Sheth, K. (1973). Inhibitors of human placental $\mathrm{C}_{19^{-}}$and $\mathrm{C}_{21^{-}} 3 \beta$-hydroxysteroid dehydrogenases. Biochim. Biophys. Acta 315, 233-249.

Hafiez, A. A., Lloyd, E. W., and Bartke, A. (1972). The role of prolactin in the regulation of testis function: The effects of prolactin and luteinizing hormone on the plasma levels of testosterone and androstenedione in hypophysectomized rat. $J$. Endocrinol. 52, 327-332.

Hall, P. F., and Eik-Nes, K. B. (1964). The effect of interstitial cell-stimulating hormone on the production of pregnenolone by rabbit testis in the presence of an inhibitor of $17 \alpha$-hydroxylase. Biochim. Biophys. Acta 86, 604-609.

Hall, P. F., and Young, D. G. (1968). Site of action of trophic hormones upon the biosynthetic pathways to steroid hormones. Endocrinology 82, 559-568.

Huang, F. L., and Chang, Y. S. (1980). The gonadotropic stimulation of androgen production on carp testis in vitro. Proc. Nat. Sci. Counc. ROC 4, $392-400$.

Idler, D. R., Hwang, S. J., and Basar, L. S. (1975). Fish gonadotropin(s). I. Bioassay of salmon gonadotropin(s) in vitro with immature trout gonads. Endocrinol. Res. Commun. 2, 199-213. 
Jean, W. C. (1980). "The Effect of Pike Eel Gonadotropin on the Content of Carp Plasma Androgen." Masters thesis. Department of Zoology, National Taiwan Univ.

Kahnt, F. W., and Neher, R. (1966). Über die adrenale steroid-biosynthese in vitro. III. Selektive hemmung der nebennierenrinden-funktion. Helv. Chim. Acta 49, 725-732.

Kuehl, F. A. Jr., Humes, J. L., Tarnoff, J., Cirillo, V. J., and Ham, E. A. (1970). Prostaglandin receptor site: Evidence for an essential role in the action of luteinizing hormone. Science 169 , 883-886.

Labhsetwar, A. P. (1974). Prostaglandins and the reproductive cycle. Fed. Proc. 33, 61-77.

Lindner, H. R., Tsafriri, A., Lieberman, H. E., Zor, U., Koch, Y., Bauminger, S., and Barnea, A. (1974). Gonadotropic action on cultured Graffian follicles: Induction of maturation division of the mammalian oocytes and differentiation of the luteal cell. Rec. Prog. Horm. Res. 30, 79-138.

Maung, Z. W., and Follett, B. K. (1977). Effects of chicken and ovine luteinizing hormone on androgen release and cyclic AMP production by isolated cells from the quail testis. Gen. Comp. Endocrinol. 33, 242-253.

McNatty, K. P., Henderson, K. M., and Sawers, R. S. (1975). Effects of prostaglandin $F_{2 \alpha}$ and $E_{2}$ on the production of progesterone by human granulosa cells in tissue culture. J. Endocrinol. 67, 231-240.

Mendelson, C., Dufau, M., and Catt, K. J. (1975). Dependence of gonadotropins-induced steroidogenesis upon RNA and protein synthesis in the interstitial cells of the rat testis. Biochim. Biophys. Acta 411, 222-230.

Moyle, W. R., Moudgal, N. R., and Greep, R. O. (1971). Cessation of steroidogenesis in Leydig cell tumors after removal of luteinizing hormone and adenosine cyclic 3',5'-monophosphate. J. Biol. Chem. 246, 4978-4982.

Muller, C. H. (1977). Plasma 5-dihydrotestosterone and testosterone in the bullfrog, Rana catesbeiana: Stimulation by bullfrog LH. Gen. Comp. Endocrinol. 33, 122-132.

Neal, P., Baker, T. G., McNatty, K. P., and Scaramuzzi, R. J. (1975). Influence of prostaglandins and human chorionic gonadotropin on progesterone concentration in organ culture. $J$. Endocrinol. 65, 19-25.

Patwardhan, U. V., and Lanthier, A. (1977). Effect of prostaglandin on the in vitro biosynthesis of estrone, estradiol and progesterone by rabbit ovarian follicles. J. Steroid Biochem. 8, 777-780.

Purvis, L. J., Canick, J. A., Rosenbaum, J. H., Hologgitas, J., and Latif, S. A. (1973). Control of cytochrome $P-450$ in rat testis mitochondria by human chorionic gonadotropin. Arch. Biochem. Biophys. 159, 32-38.

Rommertz, F. F. G., Cooke, B. A., and van der Molen, J. J. (1974). The role of cyclic AMP in the regulation of steroid biosynthesis in testis tissue. J. Steroid Biochem. 5, 279-285.

Satre, M., and Vignais, P. V. (1974). Steroid $11 \beta$ hydroxylation in beef adrenal cortex mitochondria. Binding affinity and capacity for specific ${ }^{14} \mathrm{C}$-steroids and for ${ }^{3} \mathrm{H}$-metyrapol, an inhibitor of $11 \beta$-hydroxylation. Biochemistry 13, 2201-2209.

Shin, S., and Sato, G. H. (1971). Inhibition by actinomycin D, cycloheximide and puromycin of steroid synthesis induced by cyclic AMP in interstitial cells. Biochem. Biophys. Res. Commun. 45, 501-507.

Van der Vusse, G. J., Kalkman, M. L., and van der Molen, J. J. (1975). Endogenous steroid production in cellular and subcellular fractions of rat testis after prolonged treatment with gonadotropins. Biochim. Biophys. Acta 380, 473-485. 